\title{
Higher Education Professionals Navigating Anti-Immigration Policy for Undocumented Students
}

Zelideh R. Martinez Hoy, David H. K. Nguyen

\begin{abstract}
Higher education professionals are critical to undocumented students' educational success since their access to higher education is heavily dependent on being able to interpret and navigate policies. This study presents an analysis of policies that impact higher education access for undocumented students coupled with a qualitative case study that examines how anti-immigration policy affects the experiences of higher education professionals that worked directly with undocumented students in the state of Indiana.

The authors help readers understand the experiences and challenges facing these "pathfinders" as they attempt to navigate the mazes of federal, state, and institutional policy to help their undocumented students.

Keywords: higher education, educational policy, legal issues, undocumented students
\end{abstract}

This is the author's manuscript of the article published in final edited form as:

Martinez Hoy, Z. R., \& Nguyen, D. H. K. (2019). Higher Education Professionals Navigating Anti-Immigration Policy for Undocumented Students. Educational Policy, 0895904819857823. https://doi.org/10.1177/0895904819857823 


\section{Higher education professionals navigating anti-immigration policy for undocumented students}

Over the last few decades, the absence of federal immigration reform has created a large number of undocumented immigrants and a record number of youth entering adulthood without legal status. Every year, over 65,000 undocumented students graduate high school only to discover their futures are uncertain due to laws and policies that create additional barriers to higher education and successful entry into the workforce (Passel \& Cohn, 2009; Trivette \& English, 2017). These undocumented youth "must rely upon piece-meal policies adopted state-by-state or institution-by-institution to determine whether they can access higher education, pay affordable tuition rates, or obtain state level financial aid" (Serna, Cohen, \& Nguyen, 2017, p. 3). However, the political divide in Congress has repeatedly stalled immigration reform efforts and has left undocumented students wondering. While organizational and community initiatives have helped eliminate barriers of access for undocumented youth, large disparities still remain as a result of federal, state, and institutional policies (Anderson, 2013). While some try to open doors and create opportunity, others are not so welcoming.

In this study, some of the participants were student affairs professionals, while others entered the profession through other training. However, for the purposes of this article, we refer to both of these groups collectively as "higher education professionals." The foundation of student affairs practice is one of advocacy, support, and the creation of learning environments and experiences for students (American College Personnel Association, 1994; Chang, 2002). Student affairs professionals seek this career path with the knowledge that it is one of "strong commitment to service rather than personal gain" 
(Komives \& Woodard, 2003, p. xxii). Furthermore, given the diverse experiences and rich informal out-of-the-classroom interactions with students, their roles with students are unique. The diversity that exists on the college campus calls upon practitioners to become involved in multifaceted transformational opportunities that include social justice (Gofen, 2014). As such, many higher education professionals have been crucial allies to undocumented students helping them navigate institutional bureaucracy and advocate upon their behalf for educational success, since undocumented students lack the familiarity with the American educational system (Contreras, 2009; Oseguera, Flores, \& Burciaga, 2010).

As is the case around the country, higher education access for undocumented students has been a challenge (Nienhusser, 2013). Further, the experiences of higher education professionals vary by state, institutional policies, and the level of campus support for undocumented students and those directly working with them. In the case of Indiana, the passing of laws, such as H.B. 1402, has further challenged the work of higher education professionals battling unfavorable barriers such as access and affordability for undocumented students. These professionals' accounts represent resilience, sacrifice, and selflessness to persist and seek resolution for their students despite the uncertainty. They embody their social justice mission by understanding their students' unique needs because of historical oppression (Gildersleeve \& Ranero, 2010). Their accounts provide perspectives and examples of the challenges they face daily as professionals. Many articles have examined experiences of undocumented students, but there is little research examining experiences of their advocates pertaining to policy. We hope this article serves to address the relationship between educational policy and educational practice 
and the practical consquences of policy decisions on higher education professionals. The article demonstrates how federal, state, and institutional policies are constantly a backdrop in the work of higher education professionals and highlights how their work is important for undocumented student matriculation through higher education.

\section{National Policy Context}

In 1982, Plyler v. Doe afforded the right to a free public K-12 education to undocumented children. This was the first instance that the U.S. Supreme Court afforded equal protection to undocumented immigrants under the Equal Protection Clause of the Fourteenth Amendment of the U.S. Constitution (Chapa, 2008; Lopez, 2005; Olivas, 1995, 2004; Valencia, 2008). The Texas statute withheld state funding to school districts that enrolled and educated children who were not legally admitted into the United States and allowed school districts to deny enrollment to such students (Plyler, 1982). This discrimination would create a "lifetime of hardship" and a "permanent underclass" of individuals, and that "it is doubtful that any child may reasonably be expected to succeed in life if he is denied the opportunity to an education." (Lopez, 2005, p.1389, citing Plyler).

This equal educational opportunity does not extend to post-secondary education (Contreras, 2009), and a high school diploma is no longer sufficient to compete in today's labor market (Gonzales, 2009). There are many obstacles affecting higher education access for undocumented students, some of which were erected by the states. The federal government has not been successful resolving a crisis that it created. In 1986, Congress passed comprehensive immigration reform, which became known as "amnesty" (Baker, 1997), but politics changed a decade later and Congress passed laws that dramatically 
changed the outlook for undocumented immigrants. The Illegal Immigration Reform and Immigrant Responsibility Act (IIRIRA) denied education benefits to undocumented students if the same were not afforded to U.S. nationals (Olivas, 2004; Lopez, 2005). To correct this, since 2001 several forms of the DREAM Act have been introduced in the U.S. Congress, but it has yet to pass. In response to this restriction on state policy and the failure of Congress pass the DREAM Act, states have been passing their own legislation with varying residency requirements to reinstitute in-state tuition for undocumented students (Olivas, 2004), and a handful have also afforded state financial aid (Serna, Cohen, \& Nguyen, 2017). A number have made higher education access to undocumented students even more difficult by legislating barriers by banning enrollment, prohibiting in-state resident tuition, or not acting to provide state financial aid (Serna, Cohen, \& Nguyen, 2017; Nguyen \& Martinez Hoy, 2015).

\section{Obama's Deferred Action program}

After President Obama won his reelection, activists and proponents for the undocumented youth movement pressured him to deliver upon his campaign promise to pass legislation opening a pathway to legalization for undocumented youth (Nicholls, 2013). Given that such legislation would be difficult to pass in Congress, President Barack Obama announced on June 15, 2012, that his Administration would implement the Deferred Action for Childhood Arrivals (DACA) program (Gonzales, Terriquez, \& Ruszczyk, 2014). This program through an executive order made temporary reprieve possible for almost 1.9 million eligible undocumented youth enabling them to benefit certain rights without fear of removal proceedings (Batalova, Hooker, Capps, Bachmeier, \& Cox, 2013). However, while almost 2 million youth were eligible to receive DACA 
status, only approximately 800,000 people received approved DACA status as of fall 2017. DACA recipients are allowed to seek employment and apply for a Social Security number. To be eligible, applicants must: (1) have proof of arriving to U.S. before turning 16, (2) be younger than 31 years old as of June 15, 2012, (3) reside in the U.S. continuously for the past consecutive five years, (4) have entered the U.S. without inspection or fell out of lawful visa status before June 15, 2012, and (5) be physically present in the U.S. on June 15, 2012, and at the time of making the request for deferred action. Applicants must attend high school or a GED program or have a high school diploma or equivalent. Applicants also must not have convicted of a felony offense or pose a threat to national security or public safety.

DACA is only a temporary solution that grants "lawful presence" through prosecutorial discretion pertaining to deportation and does not grant "lawful status" or provide a pathway to legal permanent residency or citizenship. The absence of legal status presents a challenging barrier for undocumented youth to successfully integrate into the American society (Alba, Jimenez, \& Marrow, 2014; Alba \& Nee, 2003; Kasinitz, et al., 2008; Portes \& Rumbaut, 2001; Zhou, et. al, 2008). This temporary reprieve had many undocumented youth weary of exposing themselves in fear of possible future antiimmigration policies and deportation. This fear became reality on September 5, 2017, when President Trump announced that the DACA program would end six months later. He called on Congress to act to resolve this issue through legislative means, but immediately thereafter complaints were filed and courts have issued injunctions and ordered the federal Administration to continue providing protection under DACA without accepting new applications. The status of DACA is still uncertain as lawsuits make their 
way through the judicial system, which has created anxiety and stress among undocumented immigrants and their families (Silver, 2018). For now, federal immigration programs like DACA are at best bandaid solutions to help provide higher education access to undocumented students, but they do not solve the problem as these executive action programs are not amnesty and do not provide any legal status or access to federal financial aid. Following these federal restrictions on undocumented young people, state action may enable higher education access for undocumented students.

\section{State Policy Context}

As a result of Congressional standstill on comprehensive immigration reform or any other legislation impacting undocumented students, state governments have become the primary arbiters of these laws and policies (Nguyen \& Serna, 2014; Nguyen \& Martinez Hoy, 2015; Serna, Cohen, \& Nguyen, 2017). While most of the state action on undocumented students has been to correct discriminating federal policies, some state actions have been to further intrude on the civil rights of undocumented students and racially discriminate based on colorblind policies (Nguyen \& Martinez Hoy, 2015). Undocumented students and their advocates must navigate and rely upon state legislation in order to access higher education or face state-directed barriers to college. Currently, twenty-one states have acted either by legislation, board of regents decisions, or state executive action to allow in-state resident tuition for undocumented or DACA students. A number of states have legislated to color-blindly discriminate against undocumented students by not recognizing their state residency and their college access, including Indiana.

Table 1: Overview of State Actions Banning In-State Tuition or Enrollment for Undocumented Students 


\begin{tabular}{|c|c|c|}
\hline State & $\begin{array}{c}\text { Year } \\
\text { Adopted }\end{array}$ & Notes \\
\hline Arizona & 2006 & \\
\hline Georgia & 2008 & \\
\hline South Carolina & 2008 & $\begin{array}{l}\text { This is not a ban on in-state tuition for } \\
\text { undocumented students. Instead students } \\
\text { must prove that they are in the country legally } \\
\text { to enroll at public institutions of higher } \\
\text { education. }\end{array}$ \\
\hline Indiana & 2011 & $\begin{array}{l}\text { H.B. } 1402 \text { prohibited resident tuition rates for } \\
\text { all undocumented students among other anti- } \\
\text { immigration measures. In 2013, S.B. } 207 \\
\text { passed to grandfather those enrolled in } 2011 \\
\text { to receive in-state tuition. }\end{array}$ \\
\hline Alabama & 2011 & $\begin{array}{l}\text { Same as South Carolina, however there are } \\
\text { explicit rules disallowing enrollment by } \\
\text { undocumented students. }\end{array}$ \\
\hline North Carolina & 2009 & $\begin{array}{l}\text { The state has a checkered history on this front } \\
\text { changing it policy at least five times since } \\
\text { 2001. Currently, if a student can pay out of } \\
\text { state tuition and has graduated from a North } \\
\text { Carolina high school they can legally enroll } \\
\text { at community colleges in the state. }\end{array}$ \\
\hline
\end{tabular}

Sources: National Conference on State Legislatures (2014); Nguyen \& Serna (2014); Nguyen \& Martinez Hoy (2015)

Overall, studies show that few undocumented students have taken advantage of in-state tuition laws (Dougherty, Nienhusser, \& Vega, 2010; Emma, 2013; Serna, Cohen, \& Nguyen, 2017). This suggests that although students qualify for in-state tuition, the price of college remains unaffordable (Serna, Cohen \& Nguyen, 2017). Out of the twenty-one states that permit in-state resident tuition to be granted to undocumented students, only six states have allowed undocumented students access to state financial 
aid. Although helpful, without access to federal financial aid, it is unlikely that these costbarriers can be eliminated. Federal financial aid is often the only mechanism that provides enough funds for a student to attend even the most affordable institutions (de la Rosa \& Tierney, 2006). Undocumented students also do not qualify for most private scholarships and financial aid, since most applications require recipients to have U.S. citizenship or residency. Being unable to access higher education means that opportunities for educational and employment opportunities remain significantly limited (Abrego \& Gonzales, 2010).

\section{Indiana Policy Context}

In 2011, the state legislature passed House Bill (HB) 1402 - anti-immigration legislation actively barring undocumented students from in-state resident tuition aimed at further marginalizing undocumented immigrants in our communities. Specifically, Indiana House Bill 1402 (2011) "provides that an individual who is not lawfully in the United States is not eligible to pay the resident tuition rate that is determined by the state educational institution." Prior to this, six of the seven public institutions granted in-state tuition to undocumented students (Schmidt, 2013). As a result, students saw their tuitions triple to $\$ 30,200.00$ from the then-in-state rate of $\$ 8,750.00$ (Schmidt, 2013).

Two years later, Senate Bill (SB) 207 was passed, which reinstated resident tuition for those undocumented students who were enrolled during the passage of HB 1402.

Although a positive step, it only impacted an approximate 200 students (Schmidt, 2013).

Proponents of SB 207 hoped that the passage of the bill would lead to resident tuition benefits for DACA recipients, but legislators in the Indiana House were not favorable to this Obama-initiated program. However, since Indiana law provided that "[a]n individual 
who is not lawfully present in the United States is not eligible to pay the resident tuition rate that is determined by the state educational institution" (H.B. 1402, 2011) and since DACA recipients are lawfully present in the United States by prosecutorial discretion, they may be afforded in-state resident tuition at public institutions that recognize this interpretation.

Only a few Hoosier institutions of higher education interpreted the 2011 law to permit in-state resident tuition for DACA recipients. These favorable institutional policies were a relief to DACA recipients, but securing these benefits can be challenging. Outreach to students and families are difficult because these institutions are not disclosing their policy fearing retribution with more adverse legislation. There are no flyers, pamphlets, or even websites to help direct DACA recipients to seek these specific benefits. Since students learn through word of mouth, navigation from higher education professionals is critical. The political climate and the anti-immigration laws have made it difficult for higher education professionals to advocate for their students, which this study examines.

The interpretation and implementation of these policies depend on the efforts of the professionals that directly assist undocumented students navigate the bureaucracy of their institutions (Contreras, 2009; Martinez Hoy, 2014). Several studies have examined the educational experiences of undocumented students. For example, while Contreras (2009) examined the experiences of undocumented Latino students in the state of Washington, Abrego and Gonzales (2010) examined postsecondary and employment challenges for undocumented youth, and Perez et al. (2009) studied academic resilience of undocumented students. Muñoz $(2012,2013,2015,2016)$ has examined the 
experiences of undocumented college student persistence. However, there is a dearth of studies that address the experiences of the professionals that service undocumented students to help them navigate this legal and policy maze. This study attempts to bridge this gap by discussing the narratives of higher education professionals who have been working with undocumented students in the state of Indiana.

\section{Higher Education and Student Affairs Professionals}

Since the end of World War II and the massification of higher education, the role of higher education professionals on campus has grown and evolved to include educators, leaders, and mentors and advocates for college students as new student populations arrived on campus that were previously marginalized or excluded (Schwartz \& Stewart, 2017). Many times the students they serve are students who come from historically marginalized populations/low socioeconomic status, those who have familial obligations, or are first generation college students. As institutional ambassadors to the community, many of them become mentors and an extended support system to undocumented students serving as principal foundations of social support and access to information that would otherwise be unknown to these students (Southern, 2016). As a result, many student affairs professionals walk alongside their students and support them because of their internally driven professional mission (Lewis \& Ramakrishnan, 2007; Jones-Correa, $2005,2008)$ to ensure equitable educational opportunities for all students.

Higher education professionals have to learn state and federal laws affecting the student population they serve. They serve as a one-stop shop for administrators, faculty, family, and community members seeking advise. Given their own internally driven mission to serve and the external government policies that may or may not counteract this 
mission, these two aspects can influence student affairs professionals behaviors and conceptualizations of their professional roles and responsibilities (Marrow, 2009). Marrow (2009) found that while politicans and the electoral body supported antiimmigration policy to exclude undocumented students from higher education, some higher education professionals helped undocumented students access education because of their strong commitment to their profession notwithstanding state or national policy ( $\mathrm{p}$. 766). In addition, many higher education and student affairs professionals have experienced the same social justice issues their students face and recognize the political, legal, and societal anti-immigration context (Flores, 2017). Their mission-driven work to support their students can be seen as exerting their agency when at times may have been constratined in the past (Flores, 2017). Interviews conducted for this study reinforced this and indicated that these professionals' own education, family history, and bilingual and bicultural abilities contributed to their capacity to help this population of students. However, the interviews also indicated that the institutions employing these professionals do not always recognize this as assets to their institution (Martinez Hoy, 2014).

\section{Purpose of the Study}

The current investigation is a direct response to address the lapse in support of and to impact professional development for those working with this specific student population in higher education (Contreras, 2009). This paper will present professionals' experiences navigating institutional, state, federal anti-immigration policies as they serve undocumented students. This study analyzed interviews with 11 higher education professionals well-established within their communities for serving undocumented students. The following question was the focus of this case study analysis: 
1. How does anti-immigration state policy affect the experiences of higher education professionals as they attempt to support their undocumented students' access to higher education?

\section{Research Design}

The study used qualitative case study methodology to better understand and explain participant perspectives and experiences (Merriam, 2009). More specifically, Creswell (2012) defines qualitative research as "an inquiry process of understanding based on distinct methodological traditions of inquiry that explore a social or human problem" (p. 15). The researchers build a complex, holistic picture, analyzes words, reports detailed observations of informants, and conducts the study in a natural setting (Creswell, 2012). This case study entailed qualitative data collection (i.e., interviews) and qualitative case study analysis to sift, code, and identify themes and sub themes.

\section{Participant Demographics}

Using a purposeful sampling method, participants were recruited if they were higher education professionals with current or previous service experiences to undocumented students and were primary points of contact at Indiana colleges and universities. All participants were recruited from an e-mail solicitation sent to members of the Indiana Latino Higher Education Council, which is a state-wide organization of higher education professionals who work to enhance the Latino educational experience in Indiana. The goals of the organization are to: (1) advocate on behalf of Latino initiatives and serve as a resource, 2) network and support members by sharing information and resources, and (3) create partnerships to achieve the organization's mission. Membership in this organization is voluntary and professionals choose to 
become a member for a variety of reasons. Membership may provide a professional community of like-minded colleagues to socialize, a professional network of colleagues working on similar issues, a medium to address social justice issues, and an outlet to broach professional challenges. Participants' self-selection to be members exhibit their personal and/or professional interest in the organization's goals and going above and beyond their job duties, which may have served as a precursor to their experiences supporting undocumented students and their responses to the research question.

From the email solication, eleven professionally diverse higher education professionals volunteered to be a part of the study. Two identified as men and nine as women. Six of the participants worked at private institutions, while the other five were at public institutions. These professionals worked in a variety of areas that interacted with undocumented students, from community outreach, recruitment, retention, to advocacy of students at the higher education level, which included but were not limited to administrators, support staff, and student affairs personnel. The years of working experience varied from entry-level to very experienced. Since each participant was from a different institution in Indiana, their lived experiences brought forth a variety of lenses, which assisted in the data triangulation.

Generally, the work of these participants' were exceptional, but given the size of the state and the number of institutions, these 11 participants saw their work as typical for those that work with undocumented students in Indiana. Indiana has one community college system, twenty-three public four-year campuses that include university systems with multiple campuses, and forty private non-profit four-year institutions. The participants that worked at private non-profit institutions were religiously affiliated with a 
mission to serve this student population. Since student affairs work is mission-driven, participants were reluctant to see themselves as exceptional because they desired to equip themselves with accurate information to support their students, but from member checking with campus administrators and community leaders, these participants were sought after for their gained expertise.

Table 2: Select background information of participants

\begin{tabular}{ccccccc}
\hline Pseudonym & Gender & Race/Ethnicity & Age & Years in & Institutional & Level of \\
& & & group & higher & type & administ- \\
& & & & education & & ration \\
\hline Martha & Female & Latino & $25-34$ & 6 & Private & Mid-level \\
Laura & Female & White & $25-34$ & 4 & Public & Entry \\
Eric & Male & Latino & $25-34$ & 3 & Private & Entry \\
Esther & Female & Latino & $35-44$ & 4 & Public & Entry \\
Kelly & Female & Latino & $25-34$ & 8 & Public & Entry \\
Lucy & Female & Latino & $25-34$ & 10 & Public & Entry \\
Elena & Female & Latino & $45-54$ & 15 & Public & Mid-level \\
Teresa & Female & Latino & $35-44$ & 9 & Private & Mid-level \\
Paul & Male & White & $25-34$ & 3 & Private & Entry \\
Cathleen & Female & White & $65+$ & $30+$ & Private & Senior \\
Marisa & Female & Latino & $35-44$ & 2 & Private & Entry \\
\hline & & & & & & \\
\hline
\end{tabular}

Participants were interviewed in a familiar environment of their choosing. They were provided a list of risks and benefits as part of their written consent. Participants' 
interviews were captured with an audio recorder and were assured names would be changed to pseudonyms to allow for anonymity.

\section{Data Analysis}

We conducted in-depth interviews that were coded and analyzed using the research question to identify themes. Data included 11 interviews ranging from 45-75 minutes long and were transcribed from audio voice digital recordings.After selecting relevant text and then organizing them into areas of repeating themes, we were able to construct a theoretical narrative (Auerbach \& Silverstein, 2003). The themes were later grouped into broad categories and then organized to describe the experiences of the higher education professionals. In order to establish trustworthiness of our interpretations, we utilized respondent validation to confirm the quality of the analysis (Elliott, Fischer, \& Rennie, 1999). Select participants' were available to provide feedback on our emergent themes and were included in this analysis. Those that assisted reviewing themes included student affairs professionals that had prior experience with serving undocumented students, as well as individuals with no exposure but had experience in higher education and were aware of anti-immigration policy impacting college campuses.

\section{Discussion of Emergent Themes}

From the semi-structured interviews, several themes emerged from their work. While each experience was unique, they all had one commonality - they worked with undocumented students because of previous experience working with Latino or underrepresented student populations, was a native Spanish-speaker, or had a bilingual/bicultural experience. Their experiences resulted in the following key themes: (1) evolving policy had a direct impact on the professionals' practice; (2) the constant 
confrontation of structural barriers forced professionals to seek, create, and demand resources to support their students; (3) professionals working with undocumented students earned their trust and served as an extended familial support system; and (4) the

in-depth, multi-layered approach to their work with undocumented students afforded them with expertise that warrants attention.

\section{Evolving policy impacts professional practice}

Since these professionals were the point of contact at their institutions, they could not avoid the ever-changing federal and state policies that immensely impacted the perceived effectiveness of their work and the ability to achieve access for their students. From the passage of HB 1402 to the DACA program, the constant implementation of discriminatory policies began to create question of their effectiveness as higher education professionals. They reflected upon feelings of powerlessness and guilt for understanding their privilege and the unjust situations of their students. However, because of their professional social justice mission, they persisted and tried to overcome these injustices alongside their students.

All of the participants noted that prior to the passing of Indiana H.B. 1402, there were challenges navigating access and obtaining uniform information for undocumented students since nothing was made official at any institution; all admissions access was through word of mouth. Lucy, who relocated to Indiana from a state that allowed in-state tuition and financial aid for undocumented students, recognized the immediate barrier that Indiana students faced. 
In [my former state], what was easy was that there was legislation. We could lean on the law to say, "Look! Financial aid! You need to be offering this information. This needs to be what everybody gets.” That was lacking [in Indiana].

Lucy also noted that the political climate in Indiana created an incentive to keep quiet about access for undocumented students.

... [I]t went from, "We don't want to address this via policy, because we're able to get people into the system quietly by knowing the right people..." After the law changed here in Indiana ..., when HB 1402 passed, then you couldn't lean on the law. In fact, the law is prohibiting the students from getting help.

Through the interviews, we learned that with the passing of H.B. 1402 some students were forced to drop out, while others only took the one or two classes they could afford.

The constant changing of the laws also forced the professionals to filter how they provided information to prospective students and their families. With the new laws, many professionals felt inadequate, overwhelmed, and incompetent to serve their students.

Laura, like other professionals, was at a loss of how to stay abreast of constantly changing information to best serve students.

[I felt overwhelmed] because that is not part of my job description at all. I do all of these extra things that none of my coworkers have to do. It's hard just keeping up with [all of the changes], and it can be really draining. It's an undocumented student in my office who has a 4.0, had done everything right, their goal has been to come to this institution, they've been admitted, and they think they are coming. Then I have to give them this crushing news? 
Similarly, because of the constant changes in laws and policies, professionals doubted their ability to serve as a resource because they were not able to impact policy that too often handcuffed them. Lucy noted:

It's that feeling of, "I'm supposed to be in this role that's able to help you. I'm supposed to be knowledgeable." I am supposed to be whom you would want to know. But I can't do anything about it. I can't help.

Lucy described a feeling that was shared by many other participants. Because of their role, they felt very frustrated and guilty that they were not able to overcome these obstacles for their students.

Even with Obama's DACA program, participants noted that there was still uncertainty. While many were optimistic that students could return to the classroom, contradicting state policy only added to the confusion. As Laura described:

When I first heard about it [referring to DACA], I thought that students would qualify for in-state tuition with deferred action, and all of the students thought that. My phone was ringing off the hook as soon as Obama made his first announcement about that. That's been especially challenging because students really have their hopes up about deferred action, and nothing has changed.

At the time of the interviews, all Indiana public institutions were fervently complying with HB 1402. They did not expect the ability to award in-state resident tuition for DACA recipients. Even currently, only less than a handful of the public institutions are working with DACA recipients to award in-state tuition. These professionals are critical to accessing these benefits since there are no institutional policies to broadly inform staff of these procedures. 
Although DACA benefited some, the uncertainty of the program sustained fear in students and their families that revealing their status may lead to deportation. Cathleen, a senior professional from a private institution noted:

There were some [that were hesitant about applying for DACA], that I didn't find out until later. They didn't apply. They said that part of the reason was that they don't trust the government. They think this deferred action plan may be taken away. Then they are going to known to be undocumented, and they will come after their parents.

Professionals struggled with the anti-immigration policy climate in Indiana; because the policies changed so often, it often created angst in the professionals' work.

All of the participants expressed feeling powerless because of the ever-changing policies. Powerlessness emerged from the inability to navigate their students successfully from admissions, to graduation, and to gainful employment. Each attributed this to the anti-immigration state laws. The feelings of powerlessness led to feelings of guilt for their privilege. Since all of the participants were either Latino or first-generation college graduates, they questioned why they were able to make it, but their students had so many obstacles.

Participants expressed concern for their students' futures. Although their students are able to pay and graduate college, the prospects of working in their desired professions may be blocked and uncertain (Abrego \& Gonzales, 2010). Martha, a mid-level professional at a private institution, reflected upon sentiments of helplessness about a former student in the community that was able to get through college but is now working in a factory. 
My students say, "I have a four year degree, but I think I'm going to have to go work back at a factory. So I'm educated, working in a factory. What are my opportunities? Why did I even go to college?" And then there's the family and community, and then they ask, "I thought you went to $[\mathrm{X}]$ College and you got your education? Why are you working in a factory? I thought you were going to be able to do something?"

Martha was frustrated that she was not able to do enough; she was unable to overcome the final barrier to find the student desirable work, especially when there is a demand for educated workers (Gonzales, 2009). Martha continued about a male student who she previously worked with. His family was upset since his sister was unable to attend. Although HB 1402 did not directly affect her private institution, the passage of the law pushed students from the public institutions to the privates hoping for financial assistance in form of private scholarships. This created a more competitive student pool, and the sister was not extended the same admissions package as her brother.

I remember having a conversation with a family because [X] College helped her brother, and now we weren't going to be able to help [the sister] because she didn't get the [X] Scholarship. I was trying to draw a painting like, "Hey, consider [the community college] as an option!” The family felt insulted; they felt offended ... That severed that relationship; the alumni brother even said, "What do you mean you can't help my sister?" But policies change from one sibling to another. The family was very upset, and they definitely went to various "higherups" to share how upset they were. 
This powerlessness often led them to feel guilty for their privilege and inability to impact positive change against these policies. Lucy reflected on this struggle.

How do I support you? I can write a letter. I can call my legislator, but beyond that, how can I support you? Well, I don't have funds to pay for your schooling, but is that the support you need? For those, I think, it's attached to the guilt, but it's not really the guilt, but it's that feeling of helplessness. I think this is partly related to the political climate. The students say “We don't want you to feel sorry for us. We just want you to stand alongside us." I don't know what it means to stand alongside you in the day to day? I vote for people who are going to support these laws, but beyond that, what does it mean? What does it mean to support you in how I do my work? What does it mean to support you in how I talk to my family? That's where a lot of the sense of guilt comes for me, because I don't know those answers.

Lucy felt guilty not being able to negotiate the challenging laws and policies against her own privilege. She was overcome with a sense of defeat. As a result, she questioned her own purpose.

[I have to manage] the privilege that I have as a citizen of the United States, as a light-colored Latina, because racism is real and when people look at me, they don't necessarily make an assumption one way or the other. How is it that I am so lucky? Why can't I share this [privilege] with other people?

Kelly also expressed guilt of her privilege. As a community leader and highly involved with the Dreamers, her powerlessness and guilt caused her to be emotional while she reflected. 
Responsibility? Guilt? Absolutely! I feel like that every time some legislation doesn't pass. In 2010, when we were all watching the Senate, and they were supposed to vote on the DREAM Act, we missed it by five or four votes. We were all watching together. We cried. But at the end of the day, I got to go home, and I had a great job. Missy and Josue, and all the people that were sitting there, their hopes were hinging on that one vote. Same thing with HB 1402 ... (crying) it sucks, and I hate it! I cry because those are my family members, but I'm still OK.

These professionals built relationships with these students, and they saw how these laws and policies crushed them. These sentiments, coupled with their sense of mission, set these professionals apart as a very resilient group advocating on behalf of their students.

Although they encountered challenges and setbacks while navigating their students, they still had the determination to persist. They had a sense of responsibility to help their students succeed because of their own privilege and the desire to pay it forward. There was a sentiment greater than a job. Martha reflected upon her identity because she sees herself in them.

I'm a first generation Latina. I'm documented but es tu gente; it's your people! Many of the students that I work with, their experience is that they came here when they were little and they see themselves as Americans. Some of them even grow up not knowing they're undocumented until they apply to college. This is when they realize, "my experience was different."

Empathizing with their students allowed these professionals to delve deeper in their students' challenges and inturn allowed them to advocate at various levels. Given 
the negative political climate, these professionals could have easily thrown up their arms. However, many expressed feeling that they were their students' only hope. Paul, an entry-level professional from a private institution, had students that yearned for his help. He described his work with students whose families owned small businesses and had financial resources to send their children to college. The students' GPA and admission requirements were on the fence, but he still saw promise and resilience.

The student actually got declined the first time, and when I told her, she was in tears and didn't understand why. I couldn't sleep at night knowing that this person did not have anywhere to go, and she doesn't want to work in a restaurant her whole life.

Paul did not take "no" for an answer. Even when his students were ready to give up, he did not allow it.

And [my students] just feel like, “Oh, he tried, but I knew it wasn't going to be for me." But I have to let them know, "This is not where you give up. This is where you try even harder!" So we take other routes.

Many of the professionals presented students with alternative paths to create options for students. Students were connected directly with other professionals at four year institutions; when a four year institution was not an option, community college connections were made. Consistently, these higher education professionals were sought by the campus and community for expertise on evolving laws and policies, as well as maintaining morale for students. But the persistence and keeping up deemed to have an emotional wear and tear on these professionals. Cathleen explained: 
Two things, I pray that I can be open, and that I don't give false hopes. Because that's the worst thing I could do. But it's heavy on my heart. I just wish I could whip out something and say, "Here's a scholarship for you!" I do talk to my spiritual director about this to know that I can't give up.

Higher education professionals from all institutional types expressed frustration and overwhelm with the constant change of laws and policies. Although those that worked at private institutions were not as impacted as those at public institutions by HB 1402, they still felt the powerlessness and guilt of the discrimination that the policies had on their students' lives.

\section{Structural barriers create navigational obstacles}

The participants noted various structural barriers from the lack of institutional infrastructure to acknowledge undocumented students to the varying resources and politics between public and private institutions. At many institutions, undocumented students were considered international because the infrastructure was not created. Eric, an entry-level admissions officer at a private institution, recalled how he had to treat his undocumented students as "other" since they did not fall into any specified categories.

A lot of the other counselors that are here think it's something foreign, because I'll have 40 files for undocumented students. They'll say, “OK. Why are these 40 applications not getting into the system, because it's making my numbers look weird." I reply, "Well, they're all undocumented." So they're like, "Are these international students applying? Are they international?" I have to repeat, "No, they're not international. They're just undocumented." 
This lack of infrastructure creates additional work and forces professionals to continually rationalize their job tasks. Admission and financial aid applications create confusion because it does not recognize students' statuses. Without any structure Lucy was reminded about a student that went from office to office trying to get help. All of these offices directed her to apply as an international student, which came with higher application fees.

But applying as an international student posed other issues. The international application fees are much higher and this misidentified the students. Elena, who was a mid-level professional at a public institution that was allowing in-state tuition for DACA recipients, stated that it was critical for undocumented students to know her and another professional so they could navigate the students to receive the in-state tuition benefit. However, students at other institutions were not so lucky.

We're [Elena and her colleague] like, "Well, if they meet the criteria that every other student meets for in-state [tuition] ... and they are DACA recipients, we don't see any reason why they cannot receive in-state tuition." Some institutions went out and said, "No! If they don't have a social security number, it doesn't matter. They are international students. They get non-resident fees."

This interpretation caused difficulty for students. Because DACA recipients have social security numbers, Elena expressed frustration that many students and their families believed they could apply for FAFSA, the Free Application for Federal Student Aid, but this is not true. Not only is federal financial aid unavailable for undocumented students, but also only a handful of states allow state financial aid, and Indiana was not one of those. 
These professionals noted lack of support in handling these matters at their institutions. This created strain, personally and professionally; Cathleen, a senior-level administrator at a private institution, recognized the need for bilingual professionals to inform parents of the college process and to convey that they would be safe on campus.

Two big things for me here that I'm pushing on; we do not have a bilingual person in admissions. We did, but we lost the person. Every time someone applies, they ask for a bilingual person, but I don't know if we offer enough money. We were one of the first colleges and universities to have our materials in Spanish, but I believe they ran out of them.

Even with some public institutions allowing in-state tuition for DACA recipients, it was clear that private institutions had more flexibility since funding options were more favorable but competitive because of the increased pool. Laura explained how she had to inform students that they did not qualify for (public) institutional scholarships because they were DACA and promoted private institutions because of the resources.

A colleague said, "I need to call these four students." I said, "I would rather do it, just since I have experience with it, and I know the resources out there." I encouraged them to consider [local community college] or a private school instead of our institution. Luckily, a lot of the students already had a plan to go to a private school, and two of them told me that they think they're going to get good scholarships at those schools.

Paul, an admissions officer at a small private school, who previousely worked at a public institution, echoed Laura's sentiments.

I have tons of support. I'm able to make decisions. There isn't as much red tape. 


\section{Building trust is critical}

All participants expressed that they had to be sensitive and gain the trust of their students and families in order to be productive. Martha elaborated:

Trust is a big factor in the community; you never want to break that trust. And so you build this hope. You build this motivation and then once reality hits, it's hard; it's hard to maintain the trust of a family when it didn't always play out how we had hoped.

Rebecca, a mid-level professional at a public institution located in a heavily populated Latino community, stressed:

They have my cell phone number. We're all in this together. Again, for undocumented students, which are the most vulnerable, I think it's essential to have that personal relationship with the students and that level of trust.

Without the student's trust it makes it difficult for the professionals to navigate them through the policy maze especially since their benefits were so reliant on their immigration status. Laura explained:

It's a hard question [referring to undocumented status], and it's hard to know how to word it without offending them. A lot of times, the students won't come out and say what they want to say. I don't know if it's that they don't feel that they can trust me or what?

Trust with their status is difficult because of experiences of confusion and transition after learning of the news (Gonzales, 2011). Trust is imperative as students reveal their status 
and their most vulnerable issues. Laura, from a public institution, recalled an awkward situation with a student's father.

For example, the daughter told me that she was undocumented, pretty much right when I went in to meet with the family. She was very upfront; very different than a lot of students. She said, "I'm undocumented." Then the dad chimed in and said, "No, you're not." She replied, "Yeah, I am.” The dad again, "We've lived here for 10 years." She said, "Yeah, dad, but that doesn't really mean that I'm not undocumented." He was like, "Yeah, it does."

Laura had to navigate this situation carefully, and she concluded by advising the family to seek legal counsel to determine their status.

For other professionals, the trust extended beyond the office and into their lives. Kelly noted,

They just become your family. For me, it has been different than my partner. He's a social worker who builds relationships with clients and may work with them on a long term, but he does not necessarily integrate his personal life into it. ICE came to the home of my students, and I remember getting a call from the mom, "I don't know what to do." They detained the dad, and the mom and daughter were by themselves. Rather than leave the daughter at home by herself, we all took turns staying with her, making sure she had someone to be with and taking mom where she needed to go. 
Participants from private institutions noted their trust was a foundational one that came from the mission of their institution coupled with their religious beliefs. Esther affirmed,

Again, for me, it's faith. I don't think that we've been put on this Earth to do just for ourselves. I truly believe that we've been put on this Earth to serve one another. I have three children of my own. I know what I wish for them and what I dream for them. These kids are no different. They're no different.

This work required building trust with their students, families, and communities. Students and families were hesitant to share their most vulnerable details but without that knowledge, these professionals could not navigate for their students. Each participant negotiated trust as their students' de facto family. This level of dedication exhibits their strong commitment in their role of creating a path to higher education.

\section{Experts in the Shadows}

From the interviews, there was a resounding theme that these professionals were experts at advocating for and navigating their undocumented students through the maze of bureaucracy. They embodied hyper vigilance to protect their students' status, particularly after the passing of HB 1402. Their expertise developed through selfexperiences, self-education, and working with others in the community. Eric, whose spouse was previously undocumented, relied mostly on his personal life.

A lot of things I relied on self-experiences. From there I had to educate myself on the ins-and-outs of things, for example, the requirements of the colleges and the difference between IB exams and AP tests ... I was pretty familiar with law and policy because I did a lot of volunteering for my church back home . 
These professionals became pseudo-community relation's officers and served as ambassadors for their institutions. The trust they built with students and families led to the community's positive perceptions of their institutions. These professionals were the "go-to" points of contact on anything "undocumented." Many times, they are the only ones who are not only bilingual but bicultural. Rebecca laughed and recalled, I am the only professional staff in student affairs that is bilingual. So if somebody had a question about anything, if any piece of information comes through that has the word "Latino" or "Hispanic" in it, it all ends up here.

When obstacles appeared in the multi-layered bureaucracy, they corrected the information and process. To ensure that students were not lost through the cracks, they walked the students and connected them to the right resources. These experiences garnered these professionals as respected administrators. Elena reflected:

Internally, in the past, I used to be the informer. I was working with various people at only certain levels of the institution. I'm actually now working with higher levels. I'm working more with VPs. I'm working more with legal counsel. Because of their experience in helping students navigate higher education, these professionals expressed feeling an obligation to stay abreast of the policies, current events, and going beyond their job to provide self-efficacy. Elena continued:

There are a couple of lawyers that I talk to, especially when it comes to making sure I gather information. When I have the right information, it gives me confidence. It empowers me to then turn around and empower other people to know what are the options and to have some kind of action plan. 
Others used their gained expertise by informing their community and profession. Martha presented often at professional conferences and recalled how opportunities snowballed after one presentation.

I took it upon myself to ask, "How do I bring this information back into the communities where it plays an impact?" Myself and other colleagues who also work with undocumented students did a presentation for the Indiana Association of College Admissions Counselors. It was a packed house of guidance counselors and admissions counselors wanting to hear how they could help recruit and retain undocumented students. Because of that, we were even asked to present at a national conference. What started off as going beyond the job description also became the reality. You become an expert.

Naturally, these professionals also became experts for their communities, advocating for their students. In the end, each of the participants became experts because of their heartfelt concern for their students. No matter how difficult, they believed that their students could succeed, because of the American Dream (Gandara \& Contreras, 2009; SuarezOrozco, Suarez-Orozco, \& Todorova, 2008).

\section{Implications}

These professionals served significant roles in the lives of their students, communities, and institutions. The findings provide implications for professionals working with undocumented students and for their institutions. Their persistence to stay abreast of the institutional, state, and federal policy, in addition to their job duties, provided them with a unique lens that is many times overlooked by administration. Despite the complex and evolving policies around DACA students, institutions should 
recognize the financial contributions they make as tuition paying students and extend the same welcoming and supportive environment it provides all other students. Building an infrastructure that accommodates for the unique needs and implementing in-service training for staff that have direct contact with undocumented students (i.e. admissions, financial aid, and advising) will ensure a smoother transition to college.

Recognizing undocumented students on applications and forms will better streamline the application process to ensure that undocumented students receive the benefits afforded to them. Because laws and policies are in flux, institutions are weary of making changes to their infrastructure. However, undocumented immigration will continue to be an issue. Even with the passage of the DREAM Act, there will continually be an undocumented student population with needs. Currently, it is very dependent on the higher education professional, and there are bound to be students who fall through the cracks. Increased funding and resources for more professionals will alleviate the workload and anticipate the increase in enrollment. Additional resources will help distribute information in high need languages.

Having a network and a safe venue to seek advice can provide support to overcome structural barriers. The participants engaged in various professional development experiences and non-profit organizations that provided an outlet. For those working in other states, it is highly recommended to seek out local networks to exchange information, strategies, and thoughts with colleagues from peer institutions.

Lastly, it is critical that higher education professionals working with undocumented students keep a sense of humor and perspective. The work can be 
draining, and professionals can get easily burned out. Cathleen, a senior level administrator, said it best.

If I don't have a good laugh once a day, I'm not fit to live with. I really have to make myself laugh. I think one can get so rotten and then it becomes bitter and resentful that you can become burnt out so soon.

Often times, in order to be in it for the long haul, professionals need to be reasonable and realistic with their time and abilities. It is more important to know resources to refer students than to know the answer to every question. Martha advised:

People used to call here and we used to try to take it up upon ourselves, but our director quickly said we're not the health experts; we're not the deferred action experts. Whatever it is, we're not the experts, but we are the bridge builders to other resources to families. That's what we're trying to do, is to provide resources to families.

The experience above assumes a best case scenario where students can be seamelessly connected to resources outside the institution so that they have their case figured out before matriculating, but because that is seldom the case, there is a continued need for the recognized role of a hired and trained individual(s) working with undocumented students for counselors and other staff to provide accurate information and ongoing support to engage in professional learning to provide access and navigate evoling policy in higher education. As Martha enthusiastically highlighted:

After we had this presentation at this national conference, I got a phone call. It was from an administrator at a community college in Texas. Out of all of the states, I would have thought a community college in Texas would have it 
together. No! She said, "Oh my gosh! I am so interested in the work that you are doing. I feel like I have no support!”

As a result, she stressed further, "Don't just do the work; share! Share what you are doing!"

\section{Conclusion}

Higher education professionals working with undocumented students demonstrate their resilience, dedication, and empathy throughout the constant fluctuation controlled by the will of law- and policymakers. This level of volatility, combined with barriers, has created challenges for these professionals and their students. Although frustrating, their commitment to their professions, social justice, and their students kept them determined, engaged, and optimistic despite the continual setbacks. As the findings from this study illustrate, there is a need for greater support and resources to work with undocumented students. Additional resources will help recognize the importance that these professionals play within their institutions, and creating networks will provide a muchneeded outlet and venue to better serve this student population.

Because of the nature of their jobs in student services and the desire to equip themselves with accurate information with the sole purpose of supporting students, participants were reluctant to call themselves experts. However, through our member checking with campus administrators and community leaders, we consistently found that once they were identified, they were sought after for their gained expertise by students and families, colleagues, and administrators. While the structures employing them never intented for them to become "experts," much less to recognize the expertise associated with a population of students that have been given a sociopolitically stigmatized status, 
the authors call for recognition of their efforts in addressing a continued need in higher education. 


\section{References}

Abrego, L., \& Gonzales, R. (2010). Blocked Paths, Uncertain Futures: The Postsecondary Education and Labor Market Prospects of Undocumented Latino Youth. Journal of Education for Students Placed at Risk, 15(1-2), 144-157.

Alba, R., Jimenez, T. R., \& Marrow, H. B. (2014). Mexican Americans as a paradigm for contemporary intra-group heterogeneity. Ethnic and Racial Studies, 37(3), 446466.

Alba, R., \& Nee, V. (2003). Remaking the American mainstream. Assimilation and Contemporary Immigration, Cambridge, MA.

American College Personnel Association. (1994). The student learning imperative: Implications for student affairs. Alexandria, VA.

Anderson, N. B. (2013). The promise of Plyler: Public institutional in-state tuition policies for undocumented students and compliance with federal law. Washington and Lee Law Review, 70(4), 2339-2388. Retrieved from https://login.libweb.lib.utsa.edu/login?url=https://search-proquestcom.libweb.lib.utsa.edu/docview/1494398916? accountid=7122.

Auerbach, C., \& Silverstein, L. (2003). Qualitative data. New York: New York University Press.

Baker, S. G. (1997). The" amnesty" aftermath: Current policy issues stemming from the legalization programs of the 1986 immigration reform and control act. International Migration Review, 5-27.

Batalova, J., Hooker, S., Capps, R., Bachmeier, J., \& Cox, E. (2013). Deferred Action for 
Childhood Arrivals at the one-year mark: A profile of currently eligible youth and applicants. Migration Policy Institute, 8 .

Chang, M. J. (2002). The impact of an undergraduate diversity course requirement on students' racial views and attitudes. The Journal of General Education, 51(1), $21-42$.

Chapa, J. (2008). A demographic and sociological perspective on Plyler's children, 1980-2005. Northwestern Journal of Law and Social Policy, 3(2), 186-200.

Contreras, F. (2009). Sin Papeles y Rompiendo Barreras: Latino Students and the Challenges of Persisting in College. Harcard Educational Review, 79(4), 610631.

Creswell, J. W. (2012). Educational Research: Planning, Conducting, and Evaluating Quantitative and Qualitative Research (4 ${ }^{\text {th }}$ Ed.). Boston, MA: Pearson.

De La Rosa, M. L., \& Tierney, W.G. (2006) Breaking through the Barriers to College: Empowering Low-Income Communities, Schools, and Families for College Opportunity and Student Financial Aid, University of Southern California Center for Higher Education Policy Analysis.

Dougherty, K. J., Nienhusser, H. K., \& Vega, B. E. (2010). Undocumented immigrants and state higher education policy: The politics of in-state tuition eligibility in Texas and Arizona. The Review of Higher Education, 34 (1). 123-173.

Elliott, R., Fischer, C. T., Rennie, D. L. (1999). Evolving guidelines for publication of qualitative research studies in psychology and related fields. British Journal of Clinical Psychology, 38(3), 215-229.

Emma, C. (2013, July 7). Immigration debate: Tuition breaks go largely unclaimed. 
Retrieved from Politico.com: http://www.politico.com/story/2013/07/an-in-statetuition-deal-that-is-largely-unclaimed-93795.html

Flores, G. M. (2017). Latina teachers: Creating careers and guarding culture. New York City: NYU Press.

Gandara, P., \& Contreras, F. (2009). The Latino education crisis. Cambridge, MA: Harvard University Press.

Gildersleeve, R. E., \& Ranero, J. J. (2010). Precollege contexts of undocumented students: Implications for student affairs professionals. New Directions for Student Success, 2010(131), 19-33.

Gofen, A. (2014). Mind the gap: Dimensions and influence of street-level divergence. Journal of Public Administration Research and Theory, 24(2), 473-493.

Gonzales, R. G. (2009). Young Lives on Hold: The College Dreams of Undocumented Students. College Board Advocacy \& Policy Center.

Gonzales, R. G. (2011). Learning to be Illegal: Undocumented Youth and Shifting Legal Contexts in the Transition to Adulthood. American Sociological Review, 76(4), 602-619.

Gonzales, R. G., Terriquez, V., \& Ruszcyk, S. P. (2014). Becoming DACAmented: Assessing the Short-Term Benefits of Deferred Action for Childhood Arrivals (DACA). American Behavioral Scientist, 58(14), 1852-1872.

House Bill 1402 (Indiana, 2011).

Jones-Correa, M. (2005). Bringing outsiders in: Questions of immigrant incorporation. In C. Wolbrecht \& R. E. Hero (Eds.), The Politics of Democratic Inclusion (pp. 75- 
102). Philadephia, PA: Temple University Press.

Jones-Correa, M. (2008). Race to the top? The politics of immigrant education in suburbia. New faces in new places: the changing geography of American immigration (pp. 308-340). New York City, NY: Russell Sage Foundation.

Kasinitz, P., Mollenkopf, J. H., Waters, M. C., \& Holdaway, J. (2008). Inheriting the City: The Children of Immigrant Come of Age, Harvard University Press: Cambridge, MA.

Kinghorn, M. (2009). Population and Employment Change in Indiana. InContext, (JulyAugust 2009). Retrieved January 9, 2015, from www.incontext.indiana.edu/2009/jul-aug/article1.asp.

Komives, S. R., \& Woodard, D. (2003). Student services a handbook for the profession (4th ed.). San Francisco, CA: Jossey-Bass.

Lewis, P. G. \& Ramakrishnan, K. (2007). Police practices in immigrant-destination cities: Political control or bureaucratic professionalism? Urban Affairs Review, 42(6), 874-900.

Lopez, M. P. (2005) Reflections on Educating Latino and Latina Undocumented Children: Beyond Plyer v. Doe. Seton Hall Law Review, 35, 1373-1385.

Marrow, H. B. (2009). Immigrant bureaucratic incorporation: The dual roles of professional missions and government policies. American Sociological Review, 74(5), 756-776.

Martinez Hoy, Z. R. (2014). The Lived Experience of Higher Education Service 
Providers Working With Undocumented Students: A Phenomenological Inquiry (Doctoral dissertation). Retrieved from ProQuest Dissertations and Theses (Accession Order No. 13301).

Merriam, S. B. (2009). Qualitative Research: A Guide to Design and Implementation. San Francisco, CA: Jossey-Bass.

Muñoz, S. M., \& Maldonaldo, M. M. (2012). Counterstories of college persistence by undocumented Mexicana students: Navigating race, class, gender, and legal status. International Journal of Qualitative Studies in Education, 25(3), 293-315.

Muñoz, S. M. (2013). “I just can't stand being like this anymore”: Dilemmas, stressors, and motivators for undocumented Mexican women in higher education. Journal of Student Affairs Research and Practice, 50(3), 233-249.

Muñoz, S. M. (2015). Identity, Social Activism, and the Pursuit of Higher Education: The Journey Stories of Undocumented and Unafraid Community Activists. Bern, Switzerland: Peter Lang.

Muñoz, S. M. (2016). Undocumented and unafraidL Understanding the disclosure management process for undocumented college students and graduates. Journal of College Student Development, 57(6), 715-729.

National Conference of State Legislatures, Undocumented Student Tuition: Overview (May 5, 2014), http://www.ncsl.org/research/education/undocumented-studenttuition-overview.aspx.

Nguyen, D. H. K., \& Martinez Hoy, Z. R. (2015). “Jim Crowing” Plyler v. Doe: The 
Resegregation of Undocumented Students in American Higher Education through Discriminatory State Tuition and Fee Legislation. Cleveland State Law Review, $63,355$.

Nguyen, D. H. K., \& Serna, G. R. (2014). Access or Barrier? Tuition and Fee Legislation for Undocumented Students across the States. The Clearing House: A Journal of Educational Strategies, Issues, and Ideas, 87(3), 124-129.

Nienhusser, H. K. (2013). Role of high schools in undocumented students' college choice. Education Policy Analysis Archieves, 21(85), n85.

Olivas, M. A. (1995). Storytelling out of school: Undocumented college residency, race, and reaction. Hastings Consitutional Law Quarterly, 22, 1019-1086.

Olivas, M. A. (2004). IIRIRA, The Dream Act, and Undocumented College Student Residency. Journal of College and University Law, 30, 435.

Oseguera, L., Flores, S. M., \& Burciaga, E. (2010). Documenting implementation realities: Undocumented immigrant students in California and North Carolina. Journal of College Admission, 206, 37-43.

Passel, J., and Cohn, D. (April 14, 2009). A Portrait of Unauthorized Immigrants in the United States. Pew Hispanic Research Center. Retrieved from: http://www.pewhispanic.org/files/reports/107.pdf.

Perez, W., Espinoza, R., Ramos, K., Coronado, H., \& Cortes, R. (2009). Academic resilience among undocumented Latino students. Hispanic Journal of Behavioral Sciences, 31(2), 149-181.

Portes, A., \& Rumbaut, R. G. (2001). Legacies: The story of the immigrant second generation. Berkeley, CA: University of California Press. 
Plyler v. Doe, 457 U.S. 202 (1982).

Schmidt, S. (2013, February 25). Senate bill could aid undocumented students. Indiana Daily Student. Retrieved January 7, 2015, from http://www.idsnews.com/article/2013/02/senate-bill-could-aid-undocumentedstudents?id=91417.

Schwartz, R. \& Stewart, D-L (2017). The history of student affairs. In J. H. Schuh, S. R. Jones, \& V. Torres (Eds.), Student Services: A Handbook for the Profession (pp. 20-38). San Francisco, CA: Jossey-Bass. /.

Senate Bill 207 (Indiana, 2013).

Serna, G. R., Cohen, J. M., \& Nguyen, D. H. K. (2017). State and institutional policies on in-state resident tuition and financial aid for undocumented students: Examining constraints and opportunities. Education Policy Analysis Archives, 25, 18. doi:10.14507/epaa.25.2809.

Silver, A. (2018). Displaced at "home": 1.5-Generation immigrants navigating membership after returning to Mexico. Ethnicities, 18(2), 208-224.

Southern, K. G. (2016). Institutionalizing support services for undocumented students at four-year colleges and universities. Journal of Student Affairs Research and Practice, 53(3), 305-318. doi:http://dx.doi.org.libweb.lib.utsa.edu/10.1080/19496591.2016.1143832.

Trivette, M. J., \& English, D. J. (2017). Finding freedom: Facilitating postsecondary pathways for undocumented students. Educational Policy, 31(6), 858-894. doi:10.1177/0895904817719526.

Valencia, R. R. (2008). Chicano students and the courts. New York: New York 
University Press.

Zhou, M., Lee, J., Vallejo, J. A., Tafoya-Estrada, R., \& Sao Xiong, Y. (2008). Success attained, deterred, and denied: Divergent pathways to social mobility in Los Angeles's new second generation. The ANNALS of the American Academy of Political and Social Science, 620(1), 37-61. 